\title{
MESENCHYMAL STEM CELLS RIF1, TCL1A, AND TERT MARKERS AS INDICATORS OF AGE ESTIMATION IN RATS
}

\author{
Fatma Mohamed Hassan ${ }^{1}$, Hoda Ahmed Mohamed Basyoni' ${ }^{1}$, Dina Sabry Abdelfattah ${ }^{2}$ \& \\ Heba Abdo Abdel Razik ${ }^{1}$
}

${ }^{\mathbf{1}}$ Forensic Medicine and Clinical Toxicology Department, Faculty of medicine, Cairo University, Egypt.

${ }^{2}$ Medical Biochemistry and Molecular Biology Department, Faculty of medicine, Cairo University, Egypt.

Corresponding author: Fatma Mohamed Hassan, Forensic Medicine and Clinical Toxicology, Faculty of medicine, Cairo University, Egypt.

E-mail address: fatmahasan.2010@yahoo.com.

Date of submission: 17 April 2020

Revised at: 6 July 2020

Accepted at: 8 July 2020

\begin{abstract}
Background: Research on stem cells has become one of the most promising and advanced scientific topics. Nevertheless, there is a lack of this type of research in the field of forensic diagnostics. Age estimation is one of the main worked-on issues in forensic practice and research. Still, there is a need to explore new complementary reliable methods. This study aimed to detect the possibility of age estimation via age-associated alteration of RIF-1 (Replication timing regulatory factor 1), TCL1A (T-cell leukemia/lymphoma-1A), and TERT (Telomerase reverse transcriptase) gene expression in rats bone marrow stem cells. Methods: Isolation of bone marrow mesenchymal stem cells from rats were undertaken at different ages; 2, 4, 6, 8, 10, and 12 weeks old. RNA extraction was performed then total RNA was reverse transcribed to cDNA to detect the quantitative expression of RIF-1, TLC1A, and TERT by using the qRT-PCR then immunoblotting. Results: There were statistically significant increases in RIF1 and TCL1A mRNA and protein expression and a decrease in TERT mRNA and protein expression with age. Conclusion: Our results showed that the mRNA and protein expression of RIF-1, TCL1A, and TERT in bone marrow cells of rats could be useful indicators for age estimation in forensic practice.
\end{abstract}

Keywords: age estimation; mRNA; RIF-1; TCL1A; TERT; mesenchymal stem cells.

\section{INTRODUCTION}

Age estimation is a pivotal factor in the study of forensic science. It can provide valuable data in cases of legal, criminal, and anthropological investigations, as well as the identification of victims of mass disasters (Zubakov et al., 2016).

Several approaches have been used for age estimation in forensic; morphological inspection, radiological investigations, and 
molecular biology analysis. Linking the morphological and radiological ones has shown significant progress still, there are some limitations. The subjectivity aspect that relies on the forensic expert's expertise to interpret the examination results. Also, the lack of universally applicable atlases; the majority of these are limited in the population area (Hartomo et al., 2019).

Using the molecular biology approach may reduce the limitations as it is based on the biomolecular alterations that occur gradually as individual ages (Feng et al., 2018). Research in this area has led to various methods; deletions of mitochondrial DNA, telomere shortening, excision circles of signal-joint-T cell receptor, aspartic acid racemization, and advanced glycation end products (Freire-Aradas et al., 2017). These methods possess the advantage of objectivity and relative accuracy, nevertheless, affected by the presence of diseases, and the specificity of tissue which limit their forensic application. So, scientists have tended to search for newer age-related markers (Deng et al., 2017; Shi et al., 2018).

Xu et al. 2011 studied the blood gene expression profile and listed 196 genes to be correlated significantly with age. Additionally, Zubakov et al. 2016 studied a group of 9 mRNA markers founded on microarray data from 222 genes expressed differently with age, of which 8 were downregulated with age (NRCAM, LRRN3, NOG, CCR7, AK5, ABLIM1, NELL2 and SLC16A10) and the most age-correlated marker among the up-regulated genes was (CFH) (Zubakov et al., 2016).

Mesenchymal stem cells (MSCs) are undifferentiated cells with the ability to potentially proliferate and differentiate into different mesenchymal tissues; bone, muscle, cartilage, fat, tendon, and marrow stroma (Hu et al., 2018).
MSCs are isolated most commonly from bone marrow, as well as other tissues like adipose tissue, dental pulp, umbilical cord blood, and amniotic fluid (Kim and Cho, 2013; Fatima et al., 2017).

The TERT (Telomerase reverse transcriptase) is a gene providing instructions for making one component of the enzyme telomerase which controls the telomeres structure. One of the molecular pathways attributed to aging in humans and other mammals is the progressive attrition of telomeres. Telomerase is highly active in rapidly dividing cells; bone marrow cells and cells that line the lungs and gastrointestinal tract (Newbold, 2002; López-Otín et al., 2013; Genetics Home Reference, 2019).

Rif1 gene (Replication timing regulatory factor 1) encodes a protein that was initially recognized in budding yeast as a Rap1 interacting factor 1 which regulates the length of telomeres in a negative way. Rif1 has a ubiquitous expression in bone marrow and testis of humans and is also expressed highly in mice embryonic stem cells and germ cells (Adams and McLaren, 2004; Dan et al., 2014).

TCL1A gene (T-cell leukemia/lymphoma-1A) is a protein coding gene. It is expressed in normal bone marrow and peripheral lymphocytes at low levels (Paduano et al., 2018). Its expression was found to be significantly associated with age

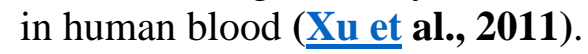

Approaches focused on stem cells have become one of the most promising and advanced scientific topics (Zakrzewski et al., 2019). However, in the field of forensic diagnostics, there is a shortage of research involving stem cells.

This study aimed to detect the possibility of age estimation via age- 
associated alterations of RIF-1, TCL1A, and TERT gene

\section{MATERIALS AND METHODS}

\section{Animals:}

Non-pregnant female (weighting 160$180 \mathrm{gm}$ ) and mature male (weighting 200$230 \mathrm{gm}$ ) Wister albino rats were collected from animal house, faculty of medicine, Cairo University, Egypt. In clean ventilated cages with a $12 \mathrm{~h}$ light/dark cycle, they were housed and supplied with a balanced rat chew diet, water, and libitum.

\section{Experimental design:}

Rats were distributed into three cages; each cage contained two females and a male. They were allowed to mate freely, and we confirmed mating by the presence of vaginal copulation plug and vaginal smear examination (Berthelot, 1981; Ochiogu et al., 2006). Pregnancy of the mated females was followed up, and pregnant ones were moved into single rat nursing cages. Following labor, the nursing rats and their pups were kept under standard conditions with free access to water and food.

Pups were randomly picked at different ages; 2, 4, 6, 8, 10, and 12 weeks old, and sacrificed by cervical dislocation (10 pups per age). Bone marrow samples were obtained immediately after the sacrifice. The experimental work was approved by the Committee of Institutional Animal Care and Use, faculty of medicine, Cairo University.

\section{Bone marrow mesenchymal stem cells isolation and culture (BM-MSCs):}

Briefly, phosphate-buffered saline (PBS) was used for flushing BM cells obtained from rats' tibiae and femurs. Flushed BM cells were layered, centrifuged at 400x $g$ for 35 minutes in $15 \mathrm{ml}$ Ficoll-Paque (Gibco-Invitrogen, Grand Island, NY, USA).
After discarding the upper layer, a layer of a mononuclear cell were left at the interphase, which was then collected, washed twice in PBS, and centrifuged. Culture, propagation, and supplementation of isolated cells with $10 \%$ fetal bovine serum (FBS), $0.5 \%$ penicillin/ streptomycin was performed then incubated at $37{ }^{\circ} \mathrm{C}$ in $5 \%$ humidified $\mathrm{CO} 2$ till it achieves a confluence of $80-90 \%$ in 7 days (Abd El Aziz et al. 2007).

\section{RNA Extraction:}

RNAeasy Mini Kit (Qiagen) was used for total RNA isolation according to the instructions of manufacturer. Assessing the purity and quantity of the isolated RNA was performed with a NanoDrop ND-1000 spectrophotometer (Thermo Fisher Scientific, USA). Confirmation of RNA integrity was done by $1.5 \%$ agarose gel electrophoresis.

\section{qRT-PCR:}

We followed this method to detect the quantitative expression of RIF-1, TLC1A, and TERT. As instructed by the manufacturer, High capacity cDNA Reverse Transcriptase kit (Applied Biosystem, USA) was utilized for reverse transcription of total RNA to complementary DNA (cDNA). Syber Green I PCR Master Kit (Fermentas) was used for amplification of cDNA by Step One instrument (Applied Biosystem, USA). The PCR conditions consisted of 10 minutes for enzyme activation at $95{ }^{\circ} \mathrm{C}$ followed by 40 cycles of denaturation at $95^{\circ} \mathrm{C}$ for 15 seconds, annealing at $55^{\circ} \mathrm{C}$ for 20 seconds, and 30 seconds at $72{ }^{\circ} \mathrm{C}$ for the extension. $\beta$ actin was used as an endogenous control. Table (1) demonstrates the primer sequences of target and reference genes. We utilized 1 $\mu \mathrm{M}$ of both gene-specific primers. A negative control sample was included, and all samples were performed in duplicates. Differences in the expression of each target gene were 
standardized comparative to $\beta$-actin mean critical threshold (CT) values of the same sample using the $2-{ }^{\Delta \Delta \mathrm{Ct}}$ approach (Schmittgen et al., 2000).

Table (1): Primer sequences specific for each gene

\begin{tabular}{|l|l|l|}
\hline Gene & Primer sequences: 5`-3 & GenBank accession number \\
\hline RIF-1 & $\begin{array}{l}\text { F: CGGAAATCAAACCCTGAGAA } \\
\text { R:CGTTAGCTCTGAGGGAGGTG }\end{array}$ & NM_001109601.1 \\
\hline TLC1A & $\begin{array}{l}\text { F: ACTGTTGGACTCTGAGTAA } \\
\text { R: GCAGCCAGGGATATGCAAAC }\end{array}$ & XM_008761831.1 \\
\hline TERT & $\begin{array}{l}\text { F: CAGACATTTCCTTTACTC } \\
\text { R: ACCATATACCTGCCAGGG }\end{array}$ & NM_053423.1 \\
\hline$\beta$-actin & $\begin{array}{l}\text { F: GGC GGCACCACCATGTACCCT } \\
\text { R: AGG GGCCGGACTCGTCATACT }\end{array}$ & NM_001101.3 \\
\hline
\end{tabular}

\section{Immunoblotting:}

The used antibodies were polyclonal antibodies purchased from ThermoFisher Scientific, U.S. (RIF1: Cat \#PA5-37951, TCL1A: Cat \#PA5-17633, TERT: Cat \#PA586083).

Cells were washed in PBS for sodium dodecyl sulfate polyacrylamide gel electrophoresis, and lysed in boiling sample buffer (62.5 mM Tris-HCl pH 6.8, 1\% SDS, $10 \%$ glycerol, and 5\% $\beta$-mercaptoethanol). With lamellae buffer, the lysates were boiled for $5 \mathrm{~min}$, and to an Immobilon membrane (Millipore), the separated proteins were transferred. In 5\% non-fat dry milk, TrisHCL, $0.1 \%$ Tween 20 incubation was undertaken for $1 \mathrm{hr}$, followed by adding RIF1, TLC1A, and TERT polyclonal antibodies to one of the membranes containing specimen samples, and incubating overnight at $4{ }^{\circ} \mathrm{C}$. Then, incubation with appropriate secondary antibodies were performed for 2 hrs at room temperature. After washing twice with $1 \times$ TBS-T, densitometric analysis of the immunoblots was accomplished to measure the quantities of RIF-1, TLC1A and TERT against control sample by $\beta$-actin protein normalization using the imaging system ChemiDoc MP software (version 3) created by Bio-Rad (Hercules, CA).

\section{Statistical methods:}

Data was coded and entered using version 7 GraphPad Prism. Then, it was summarized by mean and standard deviation. We used for comparisons between groups, ANOVA (one- way analysis of variance), with Tukey's multiple comparisons when comparing more than one variable in more than two groups. P-value $<0.05$ was considered significant. Quantitative variables were correlated using Pearson correlation coefficient (Chan, 2003).

\section{RESULTS}

\section{Total RNA purity and integrity:}

Spectrophotometer results showed the values of OD260/OD280 were between 1.8 and 2.0 .

Specificity and efficiency of $R T-q P C R$ assay amplification: 
The control gene ( $\beta$-actin) and target genes (RIF-1, TLC1A, and TERT) amplification products were of expected size, and without any miscellaneous bands as found by electrophoresis. A single peak was shown in the melting curves of RIF-1, TLC1A, and TERT, and the melting temperatures were $85.8^{\circ} \mathrm{C}, 86^{\circ} \mathrm{C}$, and $81.9^{\circ} \mathrm{C}$ respectively. Such results indicated that the amplification specificity met with the qRTPCR assay criteria.

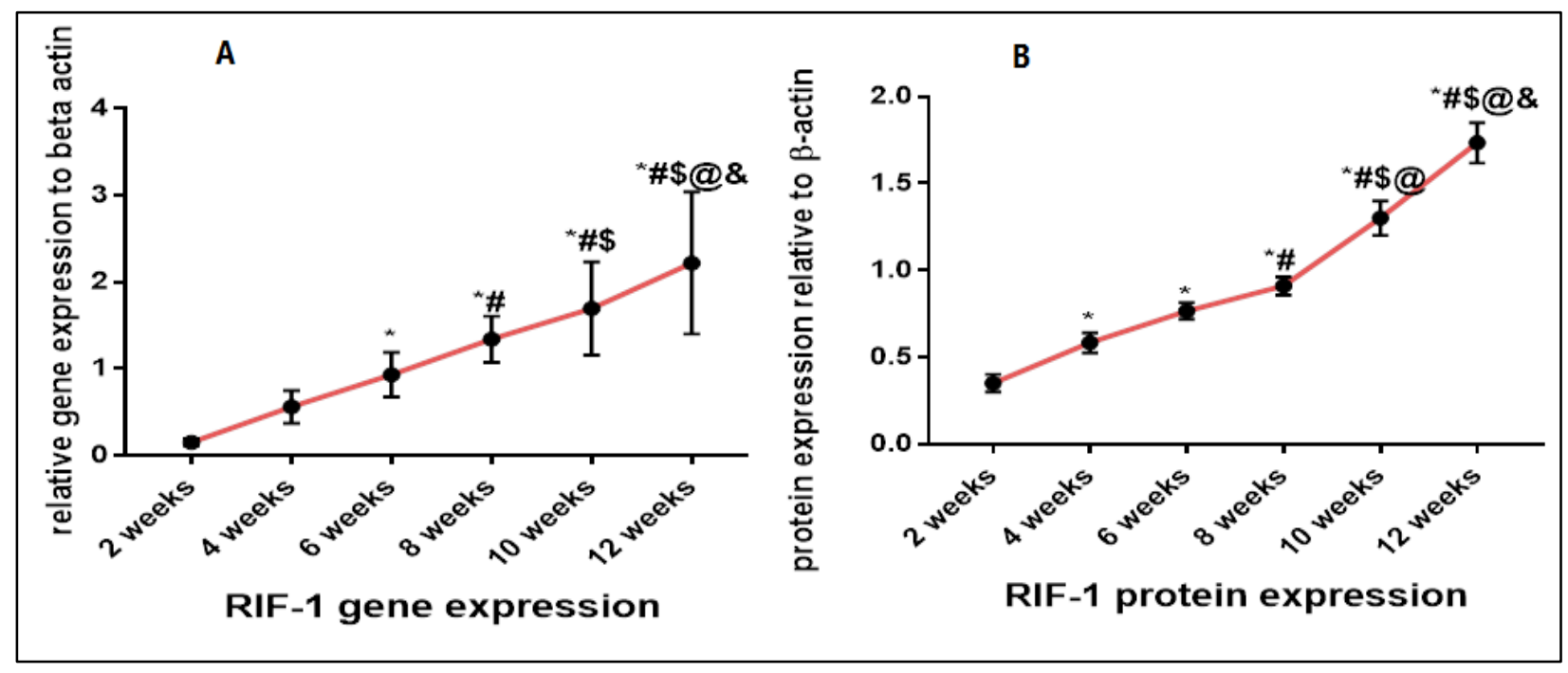

Figure (1): Pairwise comparisons for (A) RIF1 mRNA expression, and (B) RIF-1 protein expression between different ages.

Data were expressed as Mean $\pm S D$, P-value $<0.05$ was significant

(*) Denotes significant difference versus 2 weeks

(\#) Denotes significant difference versus 4 weeks

(\$) Denotes significant difference versus 6 weeks

(@) Denotes significant difference versus 8 weeks

(\&) Denotes significant difference versus 10 weeks 

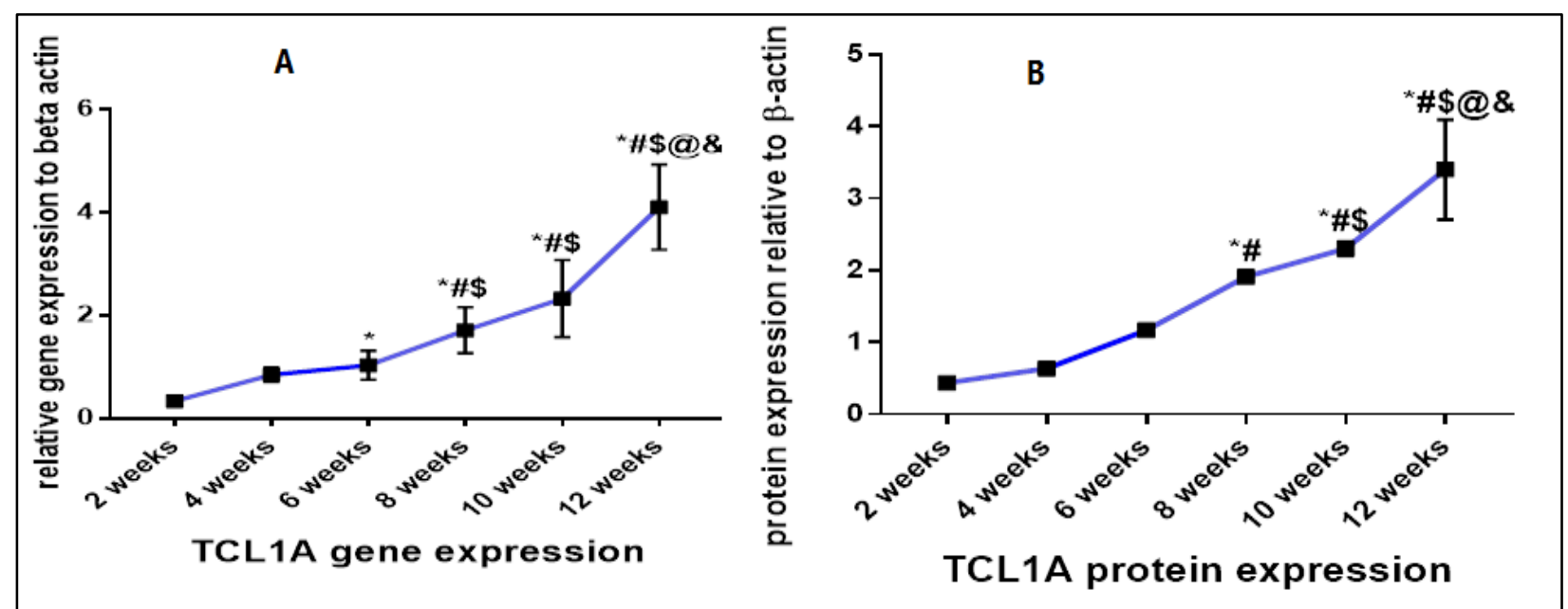

Figure (2): Pairwise comparisons for (A) TCL1A mRNA expression, and (B) TCL1A protein expression between different ages.

Data were expressed as Mean $\pm S D$, P-value <0.05 was significant

(*) Denotes significant difference versus 2 weeks

(\#) Denotes significant difference versus 4 weeks

(\$) Denotes significant difference versus 6 weeks

(@) Denotes significant difference versus 8 weeks

(\&) Denotes significant difference versus 10 weeks

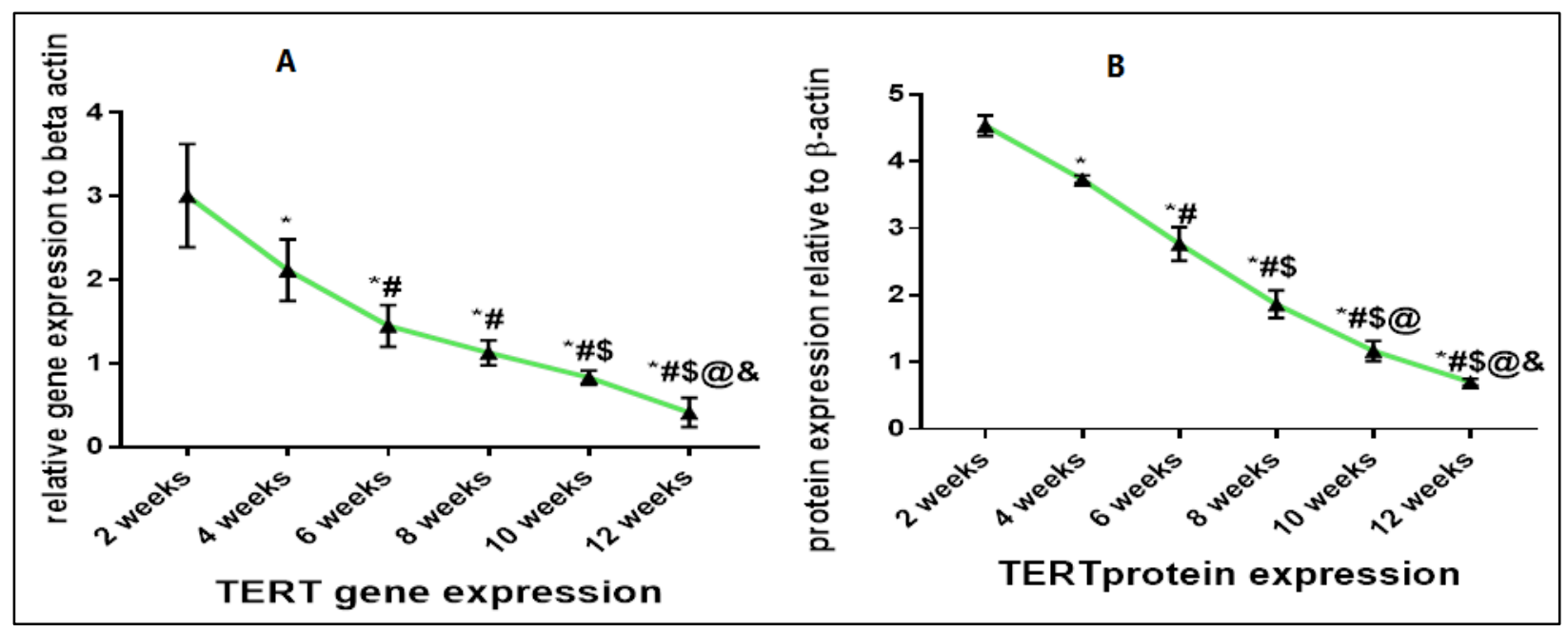

Figure (3): Pairwise comparisons for (A) TERT mRNA expression, and (B) TERT protein expression between different ages.

Data were expressed as Mean $\pm S D, P$-value $<0.05$ was significant

(*) Denotes significant difference versus 2 weeks

(\#) Denotes significant difference versus 4 weeks

(\$) Denotes significant difference versus 6 weeks

(@) Denotes significant difference versus 8 weeks

(\&) Denotes significant difference versus 10 weeks 
Pairwise comparisons for RIF1 and TCL1A mRNA expression between different ages showed that there were statistically significant increases in RIF-1 and TCL1A expression levels in 6, 8, 10 and 12 weeks groups versus to 2 weeks, in 8,10 and 12 weeks groups versus to 4 weeks, in 10 and 12 weeks groups versus to 6 weeks and in 12 weeks group compared to 8 and 10 weeks ( $\mathrm{P}$ value <0.05). Also, TCL1A expression significantly increased in 8 weeks compared to 6 weeks (P-value <0.05) (fig 1A, 2A). For TERT, there were statistically significant decreases in 4, 6, 8, 10 and 12 weeks relative to 2 weeks, in $6,8,10$ and 12 weeks relative to 4 weeks, in 10 and 12 weeks relative to 6 weeks, and in 12 weeks group relative to 8 and 10 weeks (P-value <0.05) (fig 3A).

Western Blot analysis of RIF-1, TCL1A, TERT, and B- actin proteins in bone marrow of albino rats at various studied ages showed an increase in RIF-1 and TCL1A and a decrease in TERT with increasing age (fig 4). The expression levels of these proteins showed significant differences between different ages (P-value <0.0001).

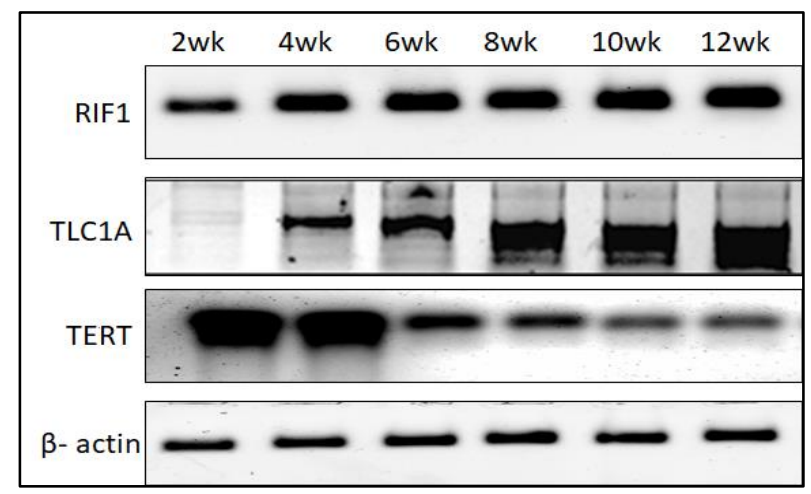

Figure (4): Western Blot analysis of RIF-1, TCL1A, TERT, and B- actin proteins in rat bone marrow at various ages.

Pairwise comparisons for the protein expression of RIF1 and TCL1A between different ages showed that there were statistically significant increases in RIF-1 and TCL1A expression levels in 8,10 and 12 weeks compared to 2 and 4 weeks, in 10 and 12 weeks compared to 6 weeks and in 12 weeks compared to 8 and 10 weeks (P-value $<0.05$ ). Also, RIF-1 expression significantly increased in 4 and 6 weeks compared to 2 weeks, and in 10 weeks compared to 8 weeks (P-value <0.05) (fig 1B and 2B). For TERT, there were statistically significant decreases in $4,6,8,10$ and 12 weeks compared to 2 weeks, in 6, 8, 10 and 12 weeks compared to 4 weeks, in 8, 10 and 12 weeks compared to 6 weeks, in 10 and 12 weeks compared to 8 weeks, and in 12 weeks versus to 10 weeks (P-value <0.05) (fig 3B).

Pearson correlation analysis showed a strong positive correlation between RIF-1 and TCL1A mRNA expression levels $(\mathrm{r}=0.97$, P-value <0.0001) (fig 5A). Also, strong negative correlations were detected between RIF-1 and TERT ( $\mathrm{r}=-0.94$, P-value $<0.0001$ ), and TCL1A and TERT mRNA expression levels $(\mathrm{r}=-0.93, \quad \mathrm{P}$-value $<0.0001$ ) (fig 5B and 5C). In addition, strong positive correlations were observed between mRNA expression levels of studied genes and their corresponding proteins; RIF-1 mRNA and its protein $(r=0.87$, P-value $<0.0001$ ), TCL1A mRNA and its protein $(\mathrm{r}=0.94$, P-value $<0.0001)$, and TERT mRNA and its protein $(\mathrm{r}=0.91, \mathrm{P}$-value $<0.0001)$ (fig 6A, 6B, 6C).

\section{DISCUSSION}

The estimation of the age of cadavers, human remains, and the living has gained significant attention in forensic medicine, in which it is a commonly used method for identification of individuals (Ren et al., 2009).

In this study, we explored a novel method for the determination of age by evaluating the mRNA and protein expression of three markers from rats bone marrow stem cells. 
The bone marrow provides several advantages in forensic research because of its close relationship in gene expression with blood, its delayed postmortem putrefaction, and the long-term RNA survival. Also, being a part of the immune system, elevated levels of particular genes with more variety in mRNA expression are anticipated. Moreover, bone marrow is protected by bone from exposure and direct exogenous contamination (van Doorn et al., 2011).

In this study, the alterations of RIF-1, TCL1A, and TERT mRNA expression levels were highly significant with age. This finding confirmed several studies that described the differential expression of genes with age in various tissues (skeletal muscle, liver, brain, and skin) (Lee et al., 1991; Lee et al., 2000; Ly et al., 2000; Dozmorov et al., 2001).

Our results showed that there were statistically significant increases in RIF1 and TCL1A mRNA expression with aging. Similarly, Xu et al. 2011 observed that RIF1 and TCL1A were significantly enriched with age while studying the variations of gene expression in human blood using Microarray.

Regarding TERT mRNA expression in our results, it showed a statistically significant decrease with age. Flores et al. 2008 found that mouse telomeres suffered significant shortening in various tissues whether differentiated or stem cells at old ages ( $>2$ years old), that was associated with a decrease in the activity of telomerase. Bodnar et al. 1998 reported that overexpression of telomerase was sufficient in culture of most human cells to prolong the life span. Also, Bernardes de Jesus et al. 2012 observed the significant extension of mice actual lifespan after transfer of TERT gene, with rise of $13 \%$ in median survival or $20 \%$ in maximum longevity (for mice treated at 1 or 2 years of age, respectively). Tomas-
Loba et al 2008 reported that overexpression of TERT in mice engineered as cancer-resistant (Sp53/Sp16/SARF/TgTERT mice) was sufficient to decrease the agerelated damage to telomeres, enhancing the median longevity by $40 \%$, and delaying aging. All these studies support our result that increasing age is associated with decreased TERT gene and protein expression.

We detected RIF-1, TCL1A, and TERT protein expression levels using Western Blot analysis which showed significant differences between age groups, with increases in RIF-1 and TCL1A, and decrease in TERT with increasing age. Moreover, Pearson correlation analysis showed strong positive correlations between mRNA expression levels of studied genes and their corresponding proteins.

This finding can be explained by changes in the respective mRNA levels. Li and Biggin 2015, and Vogel and Marcotte 2012 indicated that steady-state differences between protein levels are mainly clarified by transcript concentration variations. Schwanhäusser et al. 2011 reported that a variation of $40 \%$ in protein levels could be explained on the basis of mRNA levels. Also, Li et al. 2014 concluded that mRNA variance explained about $56 \%-84 \%$ of the protein variance, while the translation rate explained merely $9 \%$ of the variability in protein abundance.

\section{CONCLUSION}

This study showed that the mRNA and protein expression of RIF-1, TCL1A, and TERT in bone marrow cells of rats could be useful indicators for age estimation.

\section{RECOMMENDATIONS}

Further studies should be addressed to evaluate the usefulness of these markers in 
humans, and the inclusion of other stem cell tissues in forensic research.
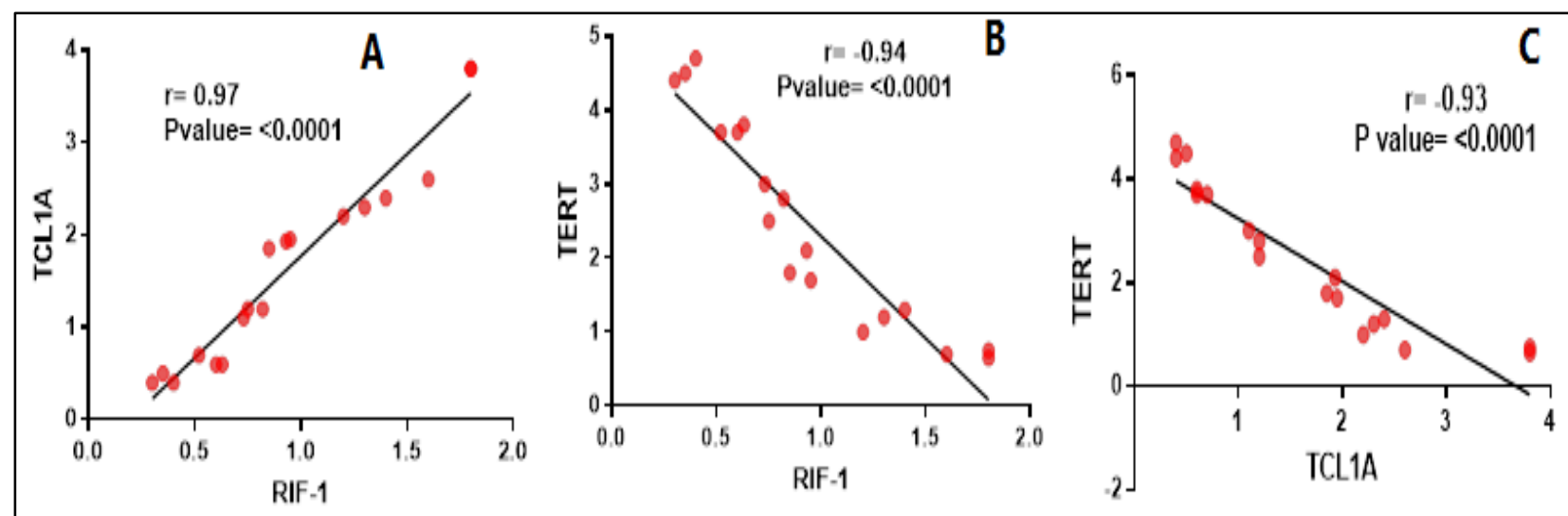

Figure (5): Pearson correlation analysis between the mRNA expression levels of studied genes in albino rats' bone marrow; (A) RIF1 and TCL1A, (B) RIF1 and TERT, (C) TCL1A and TERT.

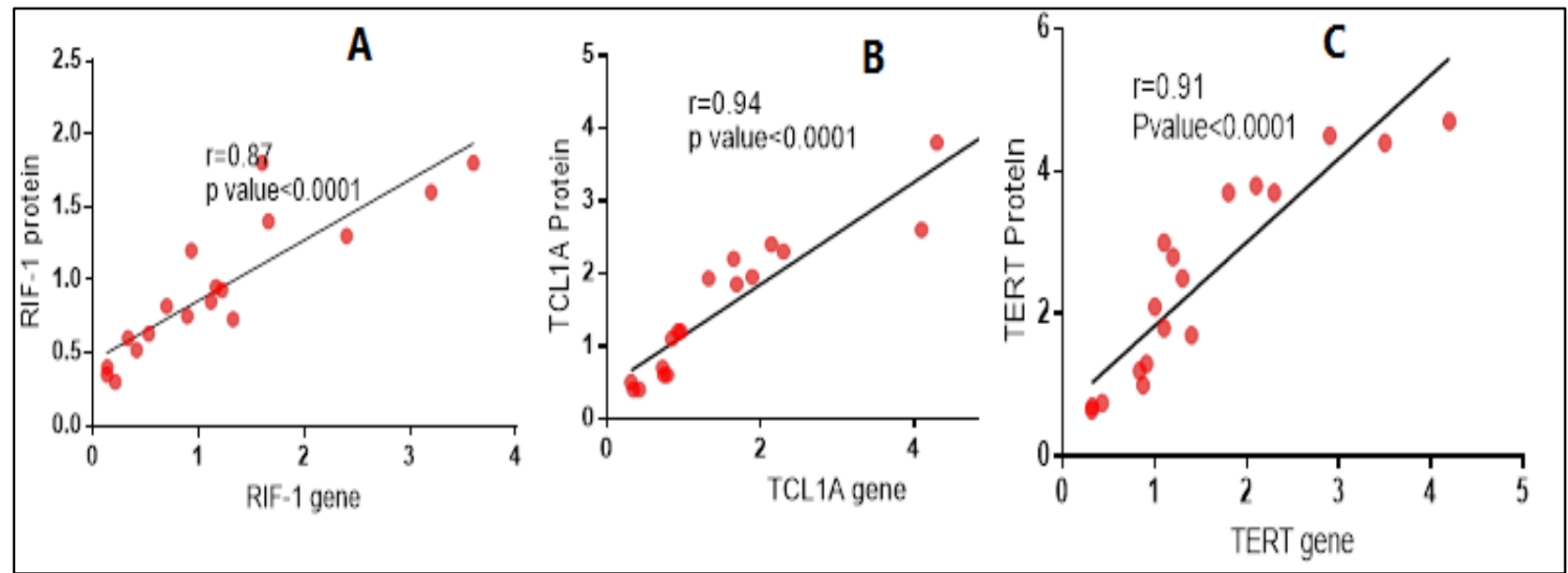

Figure (6): Pearson correlation analysis between mRNA expression levels and their corresponding proteins in albino rats' bone marrow (A) RIF1 mRNA and protein, (B) TCL1A mRNA and protein, (C) TERT mRNA and protein.

\section{REFERENCES}

Abdel Aziz, M.T.; Atta, H.M.; Mahfouz,

S.; $\quad$ Fouad, H.H.; Roshdy, N.K.; Ahmed, H.H. et al. (2007): Therapeutic potential of bone marrowderived mesenchymal stem cells on experimental liver fibrosis. Clin Biochem, 40(12):893-9. doi:10.1016/j.clinbiochem.2007.04.01 7.

Adams, I.R. and McLaren, A. (2004): Identification and Characterisation of mRif1: A Mouse Telomere-Associated Protein Highly Expressed in Germ Cells and Embryo-Derived Pluripotent 
Stem Cells. DEVELOPMENTAL DYNAMICS, 229:733-744. doi: 10.1002/dvdy.10471.

Bernardes de Jesus, B.; Vera, E.; Schneeberger, K. Tejera, A.M.; Ayuso, E.; Bosch, F. et al. (2012): Telomerase gene therapy in adult and old mice delays aging and increases longevity without increasing cancer. EMBO Mol. Med, 4:691-704. doi: 10.1002/emmm.201200245.

Berthelot, J.Y. (1981): Mating methods to produce accurate timed pregnancy in rats. Laboratory Animal Science, 31: $180-186$.

Bodnar, A.G.; Ouellette, M.; Frolkis, M.; Holt, S.E.; Chiu, C.; Morin, G.B. et al. (1998): Extension of life-span by introduction of telomerase into normal human cells. Science, 279(5349):34952.

DOI:10.1126/science.279.5349.349.

Chan, Y.H. (2003): Biostatistics 104: correlational analysis. Singap Med J, 44(12): 614-619.

Dan, J.; Liu, Y.; Liu, N.; Chiourea, M.; Okuka, M.; Wu, T. et al. (2014): Rif1 maintains telomere length homeostasis of ESCs by mediating heterochromatin silencing. Dev Cell, 29(1):7-19. doi: 10.1016/j.devcel.2014.03.004

Deng, X.D.; Gao, Q.; Zhang, W.; Zhang, B.; Ma, Y.; Zhang, L. et al. (2017): The age-related expression decline of ERCC1 and XPF for forensic age estimation: A preliminary study. J Forensic Leg Med, 49:15-19. doi: 10.1016/j.jflm.2017.05.005.

Dozmorov, I.; Bartke, A. and Miller, R. (2001): Array-based expression analysis of mouse liver genes: effect of age and of the longevity mutant Prop1df. J Gerontol A Biol Sci Med
Sci, 56(2):B72-80. doi:10.1093/gerona/56.2.b72.

Fatima, F.; Ekstrom, K.; Nazarenko, I.; Maugeri, M.; Valadi, H; Hill, A.F. et al. (2017): Non-coding RNAs in Mesenchymal Stem Cell-Derived Extracellular Vesicles: Deciphering Regulatory Roles in Stem Cell Potency, Inflammatory Resolve, and Tissue Regeneration. Front Genet, 8:161.

Feng, L.; Peng, F.; Li, S.; Jiang, L.; Sun, H.; Ji, A. et al. (2018): Systematic feature selection improves accuracy of methylation-based forensic age estimation in Han Chinese males. Forensic Sci Int Genet, 35: 38-45. doi:10.1016/j.fsigen.2018.03.009

Flores, I.; Canela, A.; Vera, E.; Tejera, A.; Cotsarelis, G. and Blasco, M.A. (2008): The longest telomeres: a general signature of adult stem cell compartments. Genes Dev, 22(5):65467. doi: 10.1101/gad.451008.

Freire-Aradas, A.; Phillips, C. and Lareu, M.V. (2017): Forensic individual age estimation with DNA: From initial approaches to methylation tests. Forensic Sci Rev, 29(2):121-144.

Genetics Home Reference (2019): TERT gene. Available at: https://ghr.nlm.nih.gov/gene/TERT (accessed September 2019).

Hartomo, B.T.; Soedarsono, N.; Dias Adrianto, A.W. and Auerkari, E.I. (2019): Review of biomolecular methods for age estimation in application of forensic odontology. AIP Conference Proceedings, 2193, 040002 https://doi.org/10.1063/1.5139364

Hu, Y.; Lou, B.; Wu, X.; Wu, R.; Gaw, L.; Pi, J. et al. (2018): Comparative Study on In Vitro Culture of Mouse Bone 
Marrow Mesenchymal Stem Cells. Stem Cells Int, 6704583. doi: 10.1155/2018/6704583.

Kim, N. and Cho, S. (2013): Clinical applications of mesenchymal stem cells. Korean J Intern Med, 28:387-402 http://dx.doi.org/10.3904/kjim.2013.28 .4 .387

Lee, C.K.,; Klopp, R.G.; Weindruch, R. and Prola, T.A. (1991): Gene expression profile of aging and its retardation by caloric restriction. Science, 285(5432):1390-3. doi:10.1126/science.285.5432.1390.

Lee, C.K.; Weindruch, R. and Prolla, T.A. (2000): Gene-expression profile of the ageing brain in mice. Nat Genet, 25(3):294-7. doi:10.1038/77046.

Li, J.J. and Biggin, M.D. (2015): Gene expression. Statistics requantitates the central dogma. Science, 347:10661067. doi: 10.1126/science.aaa8332.

Li, J.J.; Bickel, P.J. and Biggin, M.D. (2014): System wide analyses have underestimated protein abundances and the importance of transcription in mammals. PeerJ, 2:e270. doi: 10.7717/peerj.270.

López-Otín C.; Blasco M.A.; Partridge L.; Serrano, M. and Kroemer, G. (2013): The Hallmarks of Aging. Cell, 153(6): 1194-1217. doi: 10.1016/j.cell.2013.05.039

Ly, D.H.; Lockhart, D.J.; Lerner, R.A. and Schultz PG (2000): Mitotic misregulation and human aging. Science, 287(5462):2486-92. doi:10.1126/science.287.5462.2486

Newbold R.F. (2002): The significance of telomerase activation and cellular immortalization in human cancer.
Mutagenesis, $\quad$ 17(6):539-550.

https://doi.org/10.1093/mutage/17.6.53

9

Ochiogu, I.S.; Uchendu, C.N. and Ihedioha, J.I. (2006): A new and simple method of confirmatory detection of mating in albino rats (Rattus norvegicus). Animal Research International, 3(3): $527-530$. doi.org/10.4314/ari.v3i3.40784

Paduano, F.; Gaudio, E.; Mensah, A.A.; Pinton, S; Brtoni, F. and Trapasso, F. (2018): T-Cell Leukemia/Lymphoma 1 (TCL1): An Oncogene Regulating Multiple Signaling Pathways. Front Oncol, 8:317. doi: 10.3389/fonc.2018.00317.

Ren, F.; Li, C.; Xi, H.; Wen, Y.; Huang, K. (2009): Estimation of human age according to telomere shortening in peripheral blood leukocytes of Tibetan. Am J Forensic Med Pathol, 30(3):252$5 . \quad$ doi: 10.1097/PAF.0b013e318187df8e.

Schmittgen T.D.; Zakrajsek B.A.; Mills A.G.; Gorn, V; Singer, M.J. and Reed, M.W. (2000): Quantitative Reverse Transcription-Polymerase Chain Reaction to Study mRNA Decay: Comparison of Endpoint and RealTime Methods. Analytical Biochemistry, 285:194-204. doi:10.1006/abio.2000.4753

Schwanhäusser, B.; Busse, D.; Li, N.; Dittmar, G; Schuchhardt, J.; Wolf, J. et al. (2011): Global quantification of mammalian gene expression control. Nature, 473(7347):337-42. doi: 10.1038/nature10098.

Shi, L.; Jiang, F.; Ouyang, F.; Zhang, J; Wang, Z. and Shen, X. (2018): DNA methylation markers in combination with skeletal and dental ages to improve 
age estimation in children. Forensic Sci

Int Genet, 33:1-9.

doi:10.1016/j.fsigen.2017.11.005

Tomás-Loba, A.; Flores, I.; Fernández-

Marcos, P.J.; Cyuela, M.L.;

Maraver, A.; Tejera, A. et al. (2008):

Telomerase reverse transcriptase delays aging in cancer-resistant mice. Cell, 135(4):609-22. doi: 10.1016/j.cell.2008.09.034.

van Doorn, N.L.; Wilson, A.S.; Willerslev, E. and Gilbert, M.T.P. et al. (2011): Bone marrow and bone as a source for postmortem RNA. J Forensic Sci, 56(3):720-5. doi: 10.1111/j.15564029.2010.01684.x.

Vogel, C. and Marcotte, E.M. (2012): Insights into the regulation of protein abundance from proteomic and transcriptomic analyses. Nat. Rev. Genet, 13(4): 227-232. doi: $10.1038 / \mathrm{nrg} 3185$.

Xu, Q.; Ni, S.; Wu, F.; Liu, F.; Ye, X.; Mougin, B. et al. (2011): Investigation of variation in gene expression profiling of human blood by extended principle component analysis. PLoS One, 6(10):e26905. doi: 10.1371/journal.pone.0026905.

Zakrzewski, W.; Dobrzyński, M.; Szymonowicz, M. and Rybak, $\mathbf{Z}$. (2019): Stem cells: past, present, and future. Stem Cell Res Ther, 10(1):68. doi:10.1186/s13287-019-1165-5

Zubakov, D.; Liu, F.; Kokmeijer, I.; Choi, Y.; van Meurs, J.B.J.; van Ijcken, W.F.J. et al. (2016): Human age estimation from blood using mRNA, DNA methylation, DNA rearrangement, and telomere length. Forensic Sci Int Genet, 24: 33-43. doi:10.1016/j.fsigen.2016.05.014 


\title{
الملخص العربى
}

\author{
علامات ) RIF1, TCL1A, TERT) بالخلايا الجذعية الوسيطية كمؤشرات لتقدير العمر في الجرذان \\ فاطمة محمد حسن،، هدى أحمد محمد بسيونى1، دينا صبرى عبدالقتاح² و هبة عبده عبدالرازق1 \\ 1قسم الطب الثر عى و السموم الإكلينيكيةـ كلية الطب- جامعة القاهرة \\ 2 قسم الكيمياء الحيوية الطبية والبيولوجيا الجزيئيةـ كلية الطب- جامعة القاهرة
}

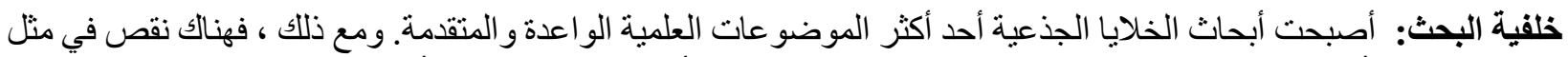

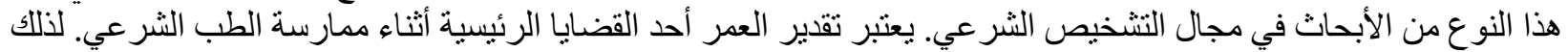

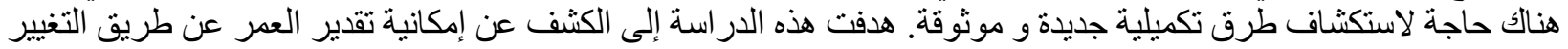

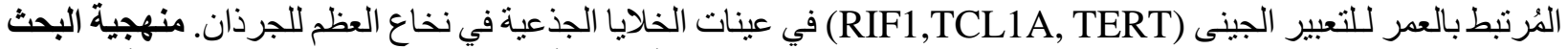

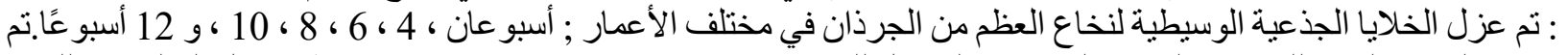

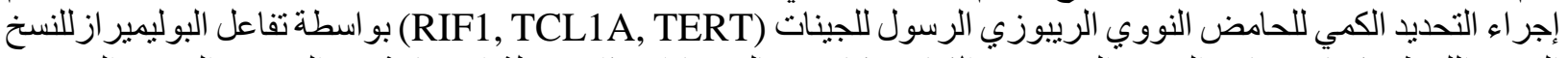

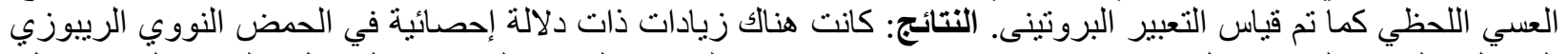

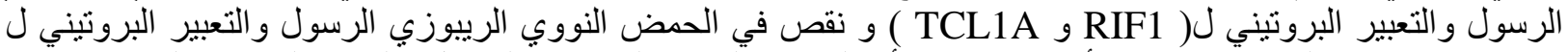
(TERT) ) في خلايا نخاع العظم في الجرذان يمكن أن تكون مؤشر ات مفيدة لتقدير العمر . TERT وTCL1A

الكلمات المفتاحية: تقدير العمر ; الحمض النووي الرييوزي الرسول ; RIF-1; TCL1A; TERT ; الخلايا الجذعية الوسيطية. 